\title{
A Study on Constraints Faced by Cauliflower Growers in Cauliflower Cultivation in Western Uttar Pradesh, India
}

\author{
Vishal Gupta ${ }^{1}$, Dan Singh ${ }^{1}$, Amit Kumar Mishra ${ }^{1}$, Brajendra Pratap Singh ${ }^{1}$, \\ Roop Kumar ${ }^{1}$ and Ravindra Kr. Pandey ${ }^{2}$ \\ ${ }^{1}$ Department of Agricultural Extension, SVBPUA\&T Modipuram, Meerut (250110), U.P., India \\ ${ }^{2}$ Department of Extension Education, NDUA\&T Kumarganj, Faizabad (224229), U.P., India \\ *Corresponding author
}

\section{A B S T R A C T}

Important vegetables grown in India are tomato, onion, brinjal, cabbage, cauliflower, okra,

Keywords

Cauliflower growers and constraints.

Article Info

Accepted:

29 June 2017

Available Online:

10 July 2017 peas etc. India contributes about 13 per cent of the world vegetable production and occupies first position in the cauliflower, second in onion and third in cabbage in the world. The present study was carried out during the year 2015-16 in Meerut district of West Uttar Pradesh. Total 80 respondents from these 2 blocks were selected by using proporsnate random sampling technique and data were collected by means of personal interview. The study revealed that overwhelming majority (81.66per cent) of cauliflower grower's had Supply of inferior quality seeds by the input dealers face to major constraints to production of cauliflowers. There are many problem faced farmer for cauliflower production. The structured schedule was developed keeping in view the objectives \& variables under study. The respondents were contacted personally for data collection. Thus this study promotes useful information about the constraints which calls for carrying out dissemination of the knowledge about constraints to the farmers of the other states.

\section{Introduction}

India ranks second in vegetables production in the world, after China. India produced 162896.9 thousand metric tons of vegetables from area of 9205.2 thousand hectares with productivity of $17.70 \mathrm{MT} / \mathrm{ha}$. (National Horticulture Board, 2013-14). Vegetables are grown in every part of our country under varied agro-climatic and soil conditions in plains as well as in hilly regions. At present, India produces about 70 different varieties of leafy fruity and starchy tuber varieties of vegetables. More than 40 kinds of vegetables belonging to different groups namely solanaceous, cucurbitacious, leguminous, cruciferous (cole crops) root crops and leafy vegetables are grown in India in tropical, subtropical and temperate regions. Important vegetables grown in India are tomato, onion, brinjal, cabbage, cauliflower, okra, peas etc. India contributes about 13 per cent of the world vegetable production and occupies first position in the cauliflower, second in onion and third in cabbage in the world. The vast production base offers India tremendous opportunities for export. During 2014-15, India exported vegetables worth Rs. 4702.78 crores. China is the leading cauliflower producing country with production of 
$8,067,917$ metric tons per year from 450 hectares area. India produces $7887 \mathrm{mt}$ of Cauliflower per year from $402 \mathrm{~m} / \mathrm{ha}$ area. In India West Bengal is a leading state in producing cauliflower followed by Uttar Pradesh.

\section{Materials and Methods}

This study was conducted in Meerut district during the year 2015-16. Meerut district comprise of 12 blocks in which two blocks namely Daurala and Sardhana were purposively selected. Four villages from Daurala and Sardhana blocks were purposively selected and 80 cauliflower growers were selected from all villages. Thus the total sample size was of 80 respondents. The data were collected through personal interview with the help of pre structured schedule. The data were analyzed and find out the percentage and rank order.

\section{Results and Discussion}

\section{Constraints faced by cauliflower growers in cultivation of cauliflower crop}

The data presented in table 1 reveals that the most important constraints related to input constraints as perceived by cauliflower growers were supply of inferior quality seeds by the input dealers, in the cultivation of cauliflower. Its mean percent score value was 81.66 and ranked in first, followed by unavailability of quality seed at the time of sowing. Its mean percent score value was 78.75 and ranked in second. High price of Hybrid seeds, fertilizers and chemicals. Its mean percent score value was 78.33 and ranked in third place. Unavailability of fertilizers and micro nutrients in proper time. Its mean percent score value was 75.83 and ranked in fourth. Reduction of soil fertility with use of higher dose of chemical fertilizers. Its mean percent score value was 74.16 and ranked in fifth place. Unavailability of quality plant protection chemicals. Its mean percent score value was 71.25 and ranked in sixth place. Lack of money to purchase requisites. Its mean percent score value was 68.75 and ranked in seventh place.

The second table constraints related to technical constraints as perceived by cauliflower growers were application of technology is highly technical in cultivation of cauliflower. Its mean percent score value was 80 and ranked in first, followed by operational difficulty in application of the technological tools due to unavailability of labour. Its mean percent score value was 79.58 and ranked in second place. Poor confidence in recommended newly technology. Its mean percent score value was 77.08 and ranked in third place. Application of plant protection measures is risky due to lack of knowledge. Its mean percent score value was 76.25 and ranked in fourth. Lack of knowledge about balance fertilizers/IPNM concept. Its mean percent score value was 75.41 and ranked in fifth place. Unavailability of technically sound labour. Its mean percent score value was 75 and ranked in sixth place. Lack of knowledge regarding planting distance. Its mean percent score value was 73.33 and ranked in seventh. Lack of knowledge about plant growth regulators. Its mean percent score value was 72.50 and ranked in eight place. Lack of knowledge regarding plant protection measures.

Its mean percent score value was 71.25 and ranked in ninth place. Lack of knowledge regarding recommended package of practices. Its mean percent score value was 70.41 and ranked in ten place.

The table 3 constraints related to sociopsychological constraints as perceived by cauliflower growers were lack of motivation and education in the cultivation of cauliflower. Its mean percent score value was 80 and ranked in first, followed by 
cauliflower enterprise is very risky. Its mean percent score value was 79.16 and ranked in second. Lack of coordination among the beneficiaries. Its mean percent score value was 76.66 and ranked in third place. Lack of active local leaders.

Its mean percent score value was 72.50 and ranked in fourth place. Field functionaries go through formalities to cover the targeted areas. Its mean percent score value was 71.25 and ranked in fifth place. Inadequate extension activities were conducted by the Govt. Department.

Its mean percent score value were 70.83 and ranked in sixth place. Local leaders are less interested in the programme. Its mean percent score value were 70.41 and ranked in seventh place.

The fourth table constraints related to general constraints as perceived by cauliflower growers were Insufficient training programmed are organized by the Govt.
Department on vegetable cultivation. Its mean percent score value was 80.83 and ranked in first, followed by insufficient demonstrations are conducted at farmers' field. Its mean percent score value was 78.75 and ranked in second. Credit facilities are not available on vegetable cultivation. Its mean percent score value was 78.33 and ranked in third place. Unavailability of labour at peak season and high charges of labour. Its mean percent score value was 75 and ranked in fourth place. Storage facilities are not available. Its mean score value were 74.58 and ranked in fifth place. Timely agricultural information is not available at proper time. Its mean percent score value was 74.16 and ranked in sixth. Short life of harvested vegetable. Its mean percent score value was 71.66 and ranked in seventh. New and timely information are not available at proper time. Its mean percent score value was 69.58 and ranked in eight. Poor transport facilities. Its mean percent score value was 47.91 and ranked in ninth. High charges of irrigation. Its mean percent score value was 45 and ranked in ten.

Table.1 Input constraints as perceived by cauliflower growers

\begin{tabular}{|c|l|c|c|c|c|c|}
\hline Sr. No. & Constraints & S.A(3) & A.(2) & D.A.(1) & MPS & Rank \\
\hline A. & $\begin{array}{l}\text { Input constraints as perceived by } \\
\text { cauliflower growers }\end{array}$ & \multicolumn{2}{|l|}{} & & \\
\hline i. & $\begin{array}{l}\text { Unavailability of quality seed at the time of } \\
\text { sowing. }\end{array}$ & 40 & 29 & 11 & 78.75 & II \\
\hline ii. & $\begin{array}{l}\text { Supply of inferior quality seeds by the input } \\
\text { dealers. }\end{array}$ & 42 & 32 & 6 & 81.66 & I \\
\hline iii. & $\begin{array}{l}\text { High price of Hybrid seeds, fertilizers and } \\
\text { chemicals }\end{array}$ & 45 & 28 & 7 & 78.33 & III \\
\hline iv. & $\begin{array}{l}\text { Unavailability of fertilizers and micronutrients in } \\
\text { proper time. }\end{array}$ & 27 & 48 & 5 & 75.83 & IV \\
\hline v. & $\begin{array}{l}\text { Reduction of soil fertility with use of higher dose } \\
\text { of chemical fertilizers. }\end{array}$ & 26 & 46 & 8 & 74.16 & V \\
\hline vi. & $\begin{array}{l}\text { Unavailability of quality plant protection } \\
\text { chemicals. }\end{array}$ & 21 & 49 & 10 & 71.25 & VI \\
\hline vii. & Lack of money to purchase requisites. & 20 & 45 & 15 & 68.75 & VII \\
\hline
\end{tabular}


Table.2 Technical constraints as perceived by cauliflower growers

\begin{tabular}{|c|c|c|c|c|c|c|}
\hline Sr. No. & Constraints & S.A(3) & A.(2) & D.A.(1) & MPS & Rank \\
\hline B. & $\begin{array}{l}\text { Technical constraints as perceived by } \\
\text { cauliflower growers }\end{array}$ & & & & & \\
\hline i. & $\begin{array}{l}\text { Lack of knowledge regarding recommended } \\
\text { package of practices. }\end{array}$ & 23 & 43 & 14 & 70.41 & $\mathrm{X}$ \\
\hline ii. & $\begin{array}{l}\text { Operational difficulty in application of the } \\
\text { technological tools due to unavailability of } \\
\text { Labour. }\end{array}$ & 33 & 45 & 2 & 79.58 & II \\
\hline iii. & Application of technology is highly technical. & 36 & 40 & 4 & 80.00 & $\mathrm{I}$ \\
\hline iv. & $\begin{array}{l}\text { Poor confidence in recommended newly } \\
\text { Technology. }\end{array}$ & 30 & 45 & 5 & 77.08 & III \\
\hline v. & $\begin{array}{l}\text { Lack of knowledge about balance } \\
\text { Fertilizers/IPNM concept. }\end{array}$ & 25 & 51 & 4 & 75.41 & $\mathrm{~V}$ \\
\hline vi. & $\begin{array}{l}\text { Lack of knowledge about plant growth } \\
\text { Regulators. }\end{array}$ & 24 & 46 & 10 & 72.50 & VIII \\
\hline vii. & $\begin{array}{l}\text { Lack of knowledge regarding plant protection } \\
\text { Measures. }\end{array}$ & 18 & 55 & 7 & 71.25 & IX \\
\hline viii. & $\begin{array}{l}\text { Lack of knowledge regarding planting } \\
\text { Distance. }\end{array}$ & 20 & 56 & 4 & 73.33 & VII \\
\hline ix. & $\begin{array}{l}\text { Application of plant protection measures is } \\
\text { Risky due to lack of knowledge. }\end{array}$ & 30 & 43 & 7 & 76.25 & IV \\
\hline $\mathbf{x}$. & Unavailability of technically sound labour. & 30 & 40 & 10 & 75.00 & VI \\
\hline
\end{tabular}

Table.3 Socio-Psychological constraints as perceived by cauliflower growers

\begin{tabular}{|c|c|c|c|c|c|c|}
\hline Sr. No. & Constraints & S.A(3) & A.(2) & \multicolumn{2}{|c|}{\begin{tabular}{|l|l|} 
D.A.(1) & MPS \\
\end{tabular}} & Rank \\
\hline C. & $\begin{array}{l}\text { Socio-Psychological constraints as perceived } \\
\text { by cauliflower growers }\end{array}$ & & & & & \\
\hline i. & Lack of motivation and education. & 35 & 42 & 3 & 80.00 & $\mathrm{I}$ \\
\hline ii. & Lack of coordination among the beneficiaries. & 29 & 46 & 5 & 76.66 & III \\
\hline iii. & $\begin{array}{l}\text { Field functionaries go through formalities to } \\
\text { Cover the targeted areas. }\end{array}$ & 17 & 57 & 6 & 71.25 & $\mathrm{~V}$ \\
\hline iv. & $\begin{array}{l}\text { Inadequate extension activities were } \\
\text { Conducted by the Govt. Department. }\end{array}$ & 18 & 54 & 8 & 70.83 & VI \\
\hline v. & Lack of active local leaders. & 24 & 46 & 10 & 72.50 & IV \\
\hline vi. & $\begin{array}{l}\text { Local leaders are less interested in the } \\
\text { Programme. }\end{array}$ & 21 & 47 & 12 & 70.41 & VII \\
\hline vii. & Cauliflower enterprise is very risky. & 33 & 44 & 3 & 79.16 & II \\
\hline
\end{tabular}


Table.4 General constraints as perceived by cauliflower growers

\begin{tabular}{|c|l|c|c|c|c|c|}
\hline Sr. No. & Constraints & S.A(3) & A.(2) & D.A.(1) & MPS & Rank \\
\hline D. & $\begin{array}{l}\text { General constraints as perceived by } \\
\text { Cauliflower growers. }\end{array}$ & & & & \\
\hline i. & $\begin{array}{l}\text { Insufficient training programmed is organized } \\
\text { by the Govt. Department on vegetable } \\
\text { Cultivation. }\end{array}$ & 36 & 42 & 2 & 80.83 & I \\
\hline ii. & $\begin{array}{l}\text { Insufficient demonstrations are conducted at } \\
\text { Farmers' field. }\end{array}$ & 32 & 45 & 3 & 78.75 & II \\
\hline iii. & $\begin{array}{l}\text { Credit facilities are not available on } \\
\text { Cauliflower cultivation. }\end{array}$ & 34 & 40 & 6 & 78.33 & III \\
\hline iv. & $\begin{array}{l}\text { Timely agricultural information are not } \\
\text { Available at proper time. }\end{array}$ & 25 & 48 & 7 & 74.16 & VI \\
\hline v. & Poor transport facilities. & 10 & 15 & 55 & 47.91 & IX \\
\hline vi. & Short life of harvested cauliflower. & 18 & 56 & 6 & 71.66 & VII \\
\hline vii. & $\begin{array}{l}\text { New and timely information are not available } \\
\text { At proper time. }\end{array}$ & 13 & 61 & 6 & 69.58 & VIII \\
\hline viii. & Storage facilities are not available. & 21 & 57 & 2 & 74.58 & V \\
\hline ix. & $\begin{array}{l}\text { Unavailability of labour at peak season and } \\
\text { High charges of labour. }\end{array}$ & 27 & 46 & 7 & 75.00 & IV \\
\hline x. & High charges of irrigation. & 8 & 12 & 60 & 45.00 & X \\
\hline
\end{tabular}

Table.5 Marketing constraints as perceived by cauliflower growers

\begin{tabular}{|c|c|c|c|c|c|c|}
\hline Sr. No. & Constraints & S.A(3) & A.(2) & \multicolumn{2}{|c|}{\begin{tabular}{l|l} 
D.A.(1) & MPS \\
\end{tabular}} & Rank \\
\hline E. & $\begin{array}{l}\text { Marketing constraints as perceived by } \\
\text { Cauliflower growers. }\end{array}$ & & & & & \\
\hline i. & Poor marketing channel. & 7 & 10 & 63 & 43.33 & VII \\
\hline ii. & $\begin{array}{l}\text { Unavailability of procurement prices of the } \\
\text { product absence of assumed marketing at } \\
\text { Remunerative price. }\end{array}$ & 9 & 68 & 3 & 69.16 & I \\
\hline iii. & $\begin{array}{l}\text { There is no cooperative society to sale } \\
\text { Cauliflower at Govt. rate. }\end{array}$ & 8 & 69 & 3 & 68.75 & II \\
\hline iv. & $\begin{array}{l}\text { Due to long distance of mother dairy the } \\
\text { Farmers are not able to sale. }\end{array}$ & 14 & 54 & 12 & 67.50 & III \\
\hline v. & $\begin{array}{l}\text { More interference of middleman in marketing } \\
\text { System. }\end{array}$ & 11 & 28 & 41 & 54.16 & IV \\
\hline vi. & Availability of market in the vicinity. & 7 & 33 & 40 & 52.91 & V \\
\hline vii. & Marketing information is not available at time. & 6 & 14 & 60 & 44.16 & $\mathrm{VI}$ \\
\hline viii. & $\begin{array}{l}\text { Police man create problem at barrier/police } \\
\text { Check post. }\end{array}$ & 4 & 9 & 67 & 40.41 & VIII \\
\hline
\end{tabular}

The fifth table constraints related to marketing constraints as perceived by cauliflower growers were unavailability of procurement prices of the product absence of assumed marketing at remunerative price. It is major problem in the cultivation of cauliflower. Its mean percent 
score value was 69.16 and ranked in first, followed by there is no cooperative society to sale cauliflower at Govt. rate. Its mean percent score value was 68.75 and ranked in second. Due to long distance of mother dairy the farmers are not able to sale. Its mean percent score value was 67.50 and ranked in third. More interference of middleman in marketing system. Its mean percent score value was 54.16 and ranked in fourth place. Availability of market in the vicinity. Its mean percent score value were 52.91 and ranked in fifth place. Marketing information is not available at time. Its mean percent score value was 44.16 and ranked in sixth. Poor marketing channel. Its mean percent score value was 43.33 and ranked in seventh. Police man create problem at barrier/police check post. Its mean percent score value was 40.41 and ranked in eight.

Thus it is concluded that there was unavailability of procurement prices of the product absence of assumed marketing at remunerative price. It was the major constraints in marketing constraints as perceived by cauliflower growers.

On the basis of the findings of the study, there are five type of constraints face by cauliflower grower. In table 1 supply of inferior quality seeds by the input dealers, In table 2 Application of technology is highly technical, in table 3 is Lack of motivation and education, In table 4 is Insufficient training programmed is organized by the Govt. Department on vegetable cultivation and in table 5 Unavailability of procurement prices of the product absence of assumed marketing at remunerative price. Given first Rank Main problem faced cauliflower growers Rank is given bases of mean response of growers.

\section{Acknowledgement}

Author is thankful to Dr. Dan Singh, Assistant Professor, Department of Extension Education, SVBPUA\&T Modipuram, Meerut -250110 (U.P.) India for his kind guidance, motivation and unconditional support for this work.

\section{References}

Ajay kumar.,Suhag ,K.S. and Bhatiya, J. K. (2011). Production and marking constraints of vegetable grower in Haryana. Haryana Journal of Agronomy, 27(1/2):74-76.

Pandit, A.: Panday, N.K.: Rana, R.K.: Kumar, N.R.: Pandit, A. and Pandey, S.K. (2003). Potato production and marketing impediments in West Bengfal.Journal of the Indian potato Association, 30(1\&2): 207-208.

Samantaray, S. K., Prusty, S. and Raj, R. K. (2009). Constraints in vegetable production -experiences of trible vegetable growers. Indian Research Journal of Extension Education. 9[3]; 3234.

Shashidhar, D. N, (2004). A study on influencing factors and constraints in drip irrigation by horticulture farmers of Bijapur district of Karnataka. M. Sc. (Agri.) Thesis, University of Agricultural Sciences, Dharwad.

Yadav, R.N, Dan Singh., V. K., Nazim Ali and Yadav, S.P. (2008). Study on sociopsychological socio-economical profit and constraints faced by the cole crops growers in Meerut District of western Uttar Pradesh. Progressive Research; 3[1]31-34.

\section{How to cite this article:}

Vishal Gupta, Dan Singh, Amit Kumar Mishra, Brajendra Pratap Singh, Roop Kumar and Ravindra Kr. Pandey. 2017. A Study on Constraints Faced by Cauliflower Growers in Cauliflower Cultivation in Western Uttar Pradesh, India. Int.J.Curr.Microbiol.App.Sci. 6(7): 2646-2651. doi: https://doi.org/10.20546/ijcmas.2017.607.373 